Jolanta MILUSKA

DOI : $10.14746 / p p .2018 .23 .4 .1$

Szczecin University

ORCID ID: https://orcid.org/0000-0002-7790-0563

Justyna KUŚWIK

Szczecin University

ORCID ID: https://orcid.org/0000-0002-3300-9373

Beata PAJAZK-PATKOWSKA

Adam Mickiewicz University in Poznań

ORCID ID: https://orcid.org/0000-0002-6509-8067

\title{
Political Activity of Women and Men - the Psychosocial Determinants of Conventional Political Activity
}

\begin{abstract}
Political activity is a type of social activity displayed by citizens. Observations and research indicate that gender can be a factor which conditions its degree and forms. Apart from biological gender, which shapes the societal roles of women and men, additional factors that are supposedly responsible for their activities include elements of the system of beliefs (i.e. acknowledged political values, conviction that political activity has an importance, level of satisfaction with democracy as well as individualism and collectivism understood as an element of individual's mentality). The impact of those factors on degree of conventional political activities among women and men is the subject of surveys which were conducted in 2004, 2010, and 2014 on a group of 1048 students from Polish universities. The received results show that differences in political activity between surveyed men and women as well as varying determinants in both groups are slowly fading away. The most important predictors of women's political activity include: conviction of its significance in democracy and (dis)satisfaction with the way it functions.
\end{abstract}

Key words: political activity, gender, women's political activity, youth, social role theory

\section{Political Activity - Theoretical Background}

D olitical activity is a form of social activity that people display. It can be perceived in a narrow and a broader way. The narrow perception, also referred to by Krystyna Skarżyńska as behavioural, denotes political behaviour and intentions or readiness to take steps within that scope. In the broader sense, apart from political behaviour and readiness to take steps within it, the notion also includes political comprehension. It refers e.g. to knowledge about political parties, well-defined political opinions and voting habits, or ability to identify people who hold the most important functions in the state (Skarżyńska, 1999).

Political participation can be understood as "an active support for political continuity or political change" or "any form of involvement in the process of affecting the governors' allocations within socially acknowledged values” (Barner-Barry, Rosenwein, 1985, as in: Skarżyńska, 2002, p. 22). For van Deth, political participation is an involvement in politics (understood in line with the Easton's model as a process of creating and allocating socially acknowledged goods) and it often refers to such activities as voting, 
participation in a political campaign, demonstrating, involvement in a riot, etc. (van Deth, 1986).

Conventional participation, which is the purpose of this article, is defined as an activity which complies with the existing constitutional order and democratic rules. Thus, it will primarily include all electoral behaviours of citizens and behaviours related to „legal influence of individuals on selection of actions undertaken by politicians" (Skarżyńska, 2002, p. 29). Barnes and Kaase (1979), in addition to the already mentioned voting, and also includes the mass media, discussions and party affiliation in conventional politics.

\section{The Role of Gender in Political Activity}

Through many decades, gender has been regarded as one of the most important factors that differentiate voting turnouts. In 1937, Tingsten analysed levels of voting turnout among women and men and concluded that men participate in elections more often than women (see also: Norris, 2007). This inequality has persisted for a very long time. Nowadays, however, the importance of gender in this area is decreasing, the level of voter turnout is equal among both genders and there are also countries where women vote more often than men, e.g. Chile, Finland or Malta (Żukowski, 2011; International IDEA, 2011). Also in the United States during all presidential elections since 1980, the percentage of women entitled to vote, who actually voted, exceeded the percentage of eligible men who did vote. However, as far asother activities related to elections, female Americans are less active than male Americans (Norris, 2007, p. 728). Still, if we analyse the aggregated results of all participating countries in the European and World Values Study, men are shown to have 5\% advantage in this field. Women are also less represented in political parties - membership in a party is declared by twice fewer women than men. This difference is lower where membership in a trade union is concerned.

The role of gender in political activity can also be considered in the context of factors that determine its level. Thus, one may wonder how gender translates into material and non-material resources, sense of effectiveness, social bonds or trust (Rosenstone, Hansen, 2003; Verba, Schlozman, Brady, 1995), which may in turn determine the greater or lesser level of political activity. The female gender is often treated as a burdensome factor due to the traditional role attributable to women. The so-called structural approach assumes that the difference observed in the levels of political activity between women and men is related to the lower position of women in the social structure (lower earnings, worse education). Eliminating the impact of those variables results in equalization of political activity levels among men and women (see also: Welch, 1977).

The role of gender in political activity may also depend on contextual factors, especially cultural factors related to the level of social modernization or religious determinants. This way of explaining the differential in political activity among women and men can be found in Hofstede (2007), as well as in the work of Inglehart and Norris (2009).

Apart from the biological gender, additional factors that are supposedly responsible for women's and men's political activities include elements of the system of beliefs, that is the acknowledged political values, conviction that political activity has an importance, 
level of satisfaction with democracy, as well as individualism and collectivism understood as an element of the individual's mentality (Reykowski, 1990).

In psychology, structural and cultural explanations of the role of gender are combined under the category of social expectations, regarding the attitudes, functions and behaviours directed at people identified as women and men" (Miluska, 1996). The structural approach, also in relation to gender, is expressed in the conviction that there is a common position occupied by certain groups in the social structure, and there are structural factors limiting our experience at all levels, from family to society (Ashmore, Del Boca, 1981; Deaux, Kite, 2002). Cultural interpretation, in turn, emphasizes that the combination of convictions, recognized values and social skills derives itself from the experience of early childhood accumulated in the process, the purpose of which is to introduce and help young people to adopt social standards (House, 1981). Some importance is attributable to various cultural values which are present in the course of socialisation (Hofstede, 2007). Roles of genders are supposed to explain current behaviours, being a direct predictor of gender differences observed in adult women and men, although they depend on distant variables, i.e. early socialization as well as biological predispositions (Eagly, 1987).

Where the concepts of gender roles are concerned it is assumed that the social system of gender roles emphasizes the following: allocating different categories of activity to people on the basis of their biological gender (professional, household, and civic), deemed necessary and useful for maintaining and improving social life; assigning to people, depending on their biological gender, oppositional personality features, expressed in the stereotypes of masculinity and femininity; and thirdly, higher valuation of everything related to masculinity (Chetwynd, Oonagh, 1978, as in: Pankowska, 2005). In the case of men, it is primarily connected with professional, rather than household activities. Professions related to exercising power (the profession of a politician is categorised as such) are assigned related features such as: independence, rationality, determination, courage, or authority (Pankowska, 2005; see also: Miluska, 1996; Pratto, 2002).

These social expectations that constitute allocated (assigned) roles may translate into subjective (internalized) roles and fulfilled (satisfied) roles. Since the role assigned to women is primarily connected with expectations related to household and private activities, we can expect lower political activity of women. On the other hand, the submissiveness and conventionality of actions, which are stereotypes associated with women, may suggest their lower interest particularly in unconventional activity.

The various factors potentially responsible for political activity of women and men indicated by the authors justify a need for further research regarding this problem, which additionally should take into account the time factor (research conducted in three periods with different characteristics defined by political events).

The aim of the study is to answer the question about extent to which gender, male and female political values, conviction about the value of political activity, the level of satisfaction with democracy, and the level of individualism and collectivism determines the level of political activity. Resolving this issue helps determining the level of activity in the group of women and men over the compared years $(2004,2010$, and 2014); what hierarchy of political values do men and women recognize; what is the value of political activity in the group of women and men; what level of satisfaction with democracy are 
typical of women and men and what is the level of individualism and collectivism in the group of women and men covered in the research.

It is assumed that level of political activity in the researched group depends on gender, which also conditions individual forms of political activity. It is expected that men will demonstrate greater political activity. Moreover, gender differences in the hierarchy of values were also assumed: men more oriented to instrumental values may have a higher political commitment than women who are oriented to expressive values. It is also expected that the political activity would be influenced by the belief in value of political activity and the level of satisfaction with democracy: in both cases, higher results should be displayed by men. Persons who appreciate activity and remain more satisfied with the democratic system, who supposedly are mostly men, would be more active in a conventional way. It is also expected that the level of political activity should be differentiated by the results achieved on the scale of individualism and collectivism. Women achieve higher results than men in terms of collectivism and thus they are likely to prefer conventional forms of activity. Levels of political activity in the men's and women's groups will also depend on the year of research which has its own political context. Considering the three periods in which the research was conducted, one may reflect on what is the influence of accompanying events on the level of political activity. Disappointment with the political class and politics in general could have discouraged political activity both in 2004 and in 2014. A similar effect could have been exacerbated by the political dispute that took place in 2010 and a certain sense of entrenchment of the political scene that accompanied citizens in that time.

\section{The Research Methodology}

We take into account results of research conducted among 1048 students of psychology and political science, including 714 women (68.13\%) and 334 men (31.87\%). 384 persons from the year 2004 (266 women and 118 men), 367 people from 2010 ( 237 women and 130 men) and 297 people from 2014 (211 women and 86 men) were surveyed. The average age for women is 23.25 years, and for men 22.98 years.

The age of the respondents indicates that they are people in the period of early adulthood (in its early phase), which begins around 20-23 years of age and lasts until reaching about 35-40 years of age (Harwas-Napierała, Trempała, 2000). In this period of human life, the physiological differences determine social development of young men and women to some extent. For men, working and being successful at work constitute the principal aim of activity. Professional life and social activity in men usually take place independently of family life, he does not exclude his activity in this area both in the matter of establishing and maintaining a family as well as often a large commitment to caring for and upbringing the children. Professional and social activity in women are being interrupted or marginalized more often due to reasons connected with parenthood. Hence, it can be concluded that women involve themselves in any political activity to a lesser extent than men. A significant change that takes place in the period of early adulthood in relation to adolescence, regarding our way of perceiving social reality, results from the fact that we have departed from the idealistic perception of the world, the "ab- 
solutist perception of truth," and adopted of relative view of the nature of solutions. Such a method of attributing value to the affects social and political attitudes.

Political activity was examined in its conventional and unconventional (legal and illegal) dimensions as well as in actual (the form of action undertaken by the surveyed person) and potential (attitudes of the surveyed towards various forms of activity) dimensions. Conventional activity, which is the purpose of this article, is understood as consistent with the order established by constitution and positioned within the framework of democratic institutions, and includes mainly the electoral activities and participation in referenda. The Political Activity Scale was used to measure political activity. It consisted of: seven questions about conventional actual activity, four questions about unconventional legal activity, two questions about conventional potential activity, three regarding unconventional legal potential activity, and five regarding unconventional illegal activity. In the case of conventional actual activity which refers to participation in elections, the following answers were available: "yes," "no," "don't recall." The scale from 1 to 5 was created and the average value was calculated basing on the number of answers "in favour." The portfolio of answers to questions about all types of potential activity included five categories: „,definitely yes,” "mostly yes,” „hard to say” „rather no," "definitely not" (the answers were scored from 4 to 0 , the number of points was summed up and then the average was calculated). In addition to the scales indicated in the questionnaire, there were two additional questions: one regarding the belief of the surveyed regarding importance of citizens' participation in elections for the functioning of democracy (the importance of political activity), and the second regarding satisfaction of the surveyed with democracy in Poland.

A modified Sotwin's (2003) scale of values has been applied to measure the hierarchy of political values. As compared to the original tool, generally defined values were put in a more detailed way. "Equality" was replaced with „equality before the law," "income equality,” „equality of opportunity,” while instead of „,reedom” - ,political freedom,” „economic freedom," "personal freedom" were used; instead of "justice:" "distribution of wealth according to contribution" and "distribution of wealth according to needs" appeared. Moreover, the following values have been removed from the scale: "tolerance," "world peace" and "political activity." All of the eight values have been paired and the surveyed persons were asked to select the value which is more important to him or her. Then the number of times each value was chosen by the surveyed was calculated, which allowed for developing the hierarchy of values.

Measurement of individualism and collectivism was done using a 20-item questionnaire developed by J. Wagner (Wagner, Moch, 1986; Wagner, 1995). It investigates five factors: 1) Stand alone: focus on independence and self-reliance, 2) Win above all: extreme inclination to win in competitive situations, 3) Group preference: preference for working with other members of the group, 4) Sacrifice in Group: conviction about the need to sacrifice the individual for the benefit of the group and 5) Individual Thinking: the need to have individual beliefs as a condition of adapting to the group. Factors 1,2 and 5 are the individualistic factors, while factors 3 and 4 and the collectivist factors.

The factor analysis has proved the existence of those five factors. Reliability of the whole scale has been confirmed in Polish research (Miluska, 2005) and equals 0.71 (Cronbach's alfa), whereas reliability of individual scales are as follows: "Reliance on 
oneself" - 0.75; "Winning" - 0.74; "Preference for the group" - 0.72, "Commitment within the group" -0.69 and "Independent attitude" -0.70 .

There is a similarity between the described structure of factors and the types of individualism and collectivism in Trandis' concept (1995). „Self-reliance” and "individual thinking" are close to horizontal individualism, which is characterized by a need to differentiate from other, partner-treated people. „Winning” is the equivalent of vertical individualism which emphasizes the value of rivalry and overtaking others, while "preference for the group" is a horizontal collectivism emphasizing importance of mutual dependence between members of a single group. "Dedication to the group" is closer to collectivism, although it does not fit into any of its types distinguished by Triandis, while the questionnaire does not contain items related to vertical collectivism, emphasizing the importance of tradition and respect for the family. The respondents answered questions using a seven-degree scale, where the answer ,1" meant „I definitely agree” and „7" - „I strongly disagree.”

The surveys have been conducted in three different years: 2004, 2010, and 2014.

\section{Research Results}

The level of conventional and actual political activity

Although the answers to the questions in the applied scale were dichotomous in nature, since it was possible to sum up the answers, the developed variable shall be perceived as continuous. If we assume that score „,

Graphs 1. The level of conventional and actual political activity

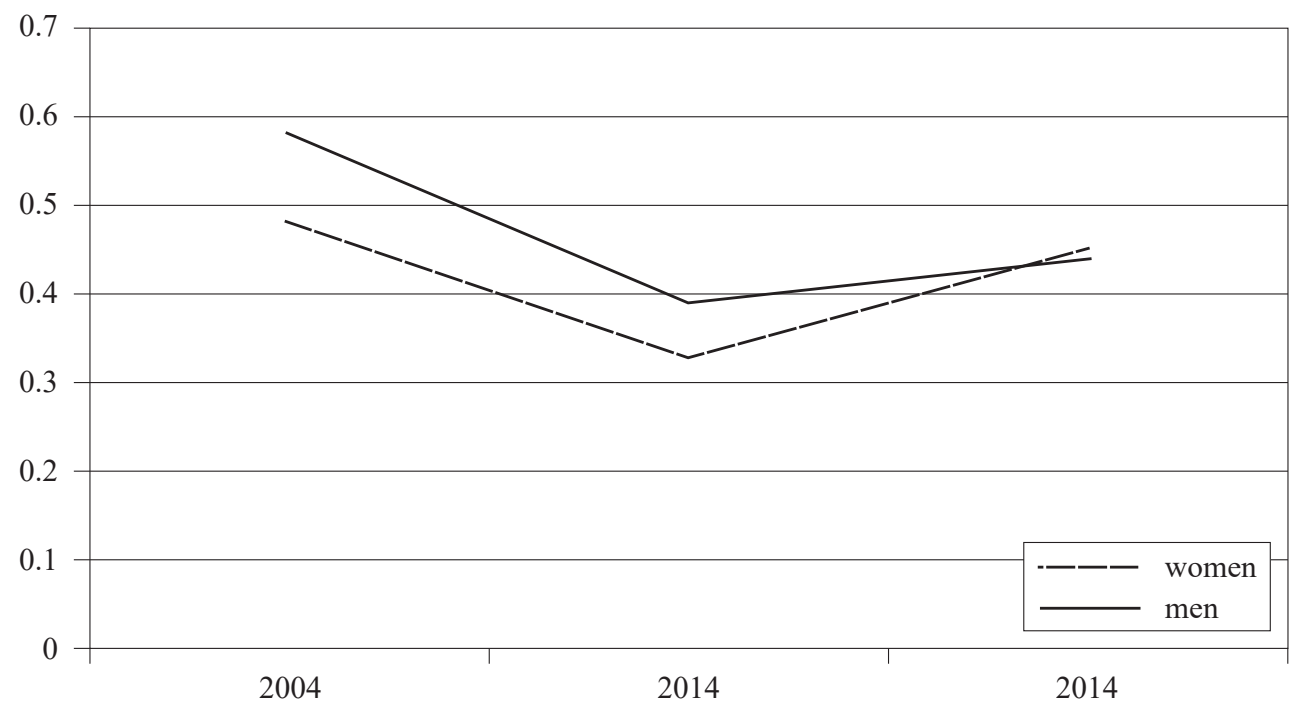

Source: Own elaboration. 
political activity, whereas score " 1 " is a proof of taking the activity, then the average for a group within all the analysed years equals $\mathrm{M}=0.44 ; \mathrm{SD}=0.23$. This is not a high level. At the same time, women reach the average of $\mathrm{M}=0.42 ; \mathrm{SD}=0.23$ and men $\mathrm{M}=0.47$, $\mathrm{SD}=0.24$. It is a statistically significant difference $\left(\mathrm{F}=9.56 ; \mathrm{p}=0.002 ; \eta^{2}=0.01\right)$. We can observe a systematic growth of conventional actual political activity among women (e.g. higher voting turnout). The average value within this group in 2004 was $\mathrm{M}=0.48$; $\mathrm{SD}=0.22$ and among men $\mathrm{M}=0.58 ; \mathrm{SD}=0.20\left(\mathrm{~F}=18.53, \mathrm{p}<0.000 ; \eta^{2}=0.05\right)$, and in 2010 in the women's group it reached the value of $\mathrm{M}=0.33 ; \mathrm{SD}=0.18$ and in the men's group $\mathrm{M}=0.39 ; \mathrm{SD}=0.20\left(\mathrm{~F}=7.11 ; \mathrm{p}=0.008 ; \eta^{2}=0.02\right)$, while in 2014 the average values in both groups have come so close to each other that the difference between them did not reach statistical significance (women $\mathrm{M}=0.45 ; \mathrm{SD}=0.25$ and men $\mathrm{M}=0.44$; $\mathrm{SD}=0.28 ; \mathrm{F}=0.11 ; \mathrm{p}=0.736$ ).

The level of conventional potential activity

The range of results achievable in relations to conventional potential activity is from " 0 " (no activity) to " 4 " (the highest intensity). The average value for the whole group in all the years has reached the level of $\mathrm{M}=2.35 ; \mathrm{SD}=0.96$, in a group of women $\mathrm{M}=2.23 ; \mathrm{SD}=0.90$, and in the group of men $\mathrm{M}=2.58, \mathrm{SD}=1.03(\mathrm{~F}=34.90 ; \mathrm{p}<0.000$; $\left.\eta^{2}=0.03\right)$.

The average result that describes levels of conventional potential activity in the women's group in 2004 was $\mathrm{M}=2.19 ; \mathrm{SD}=0.79$ and in the men's group $\mathrm{M}=2.49 ; \mathrm{SD}=1.01$ : the difference is statistically significant $\left(F=9.95 ; p=0.001 ; \eta^{2}=0.03\right)$. In 2010 , results

\section{Graph 2. The level of conventional potential activity}

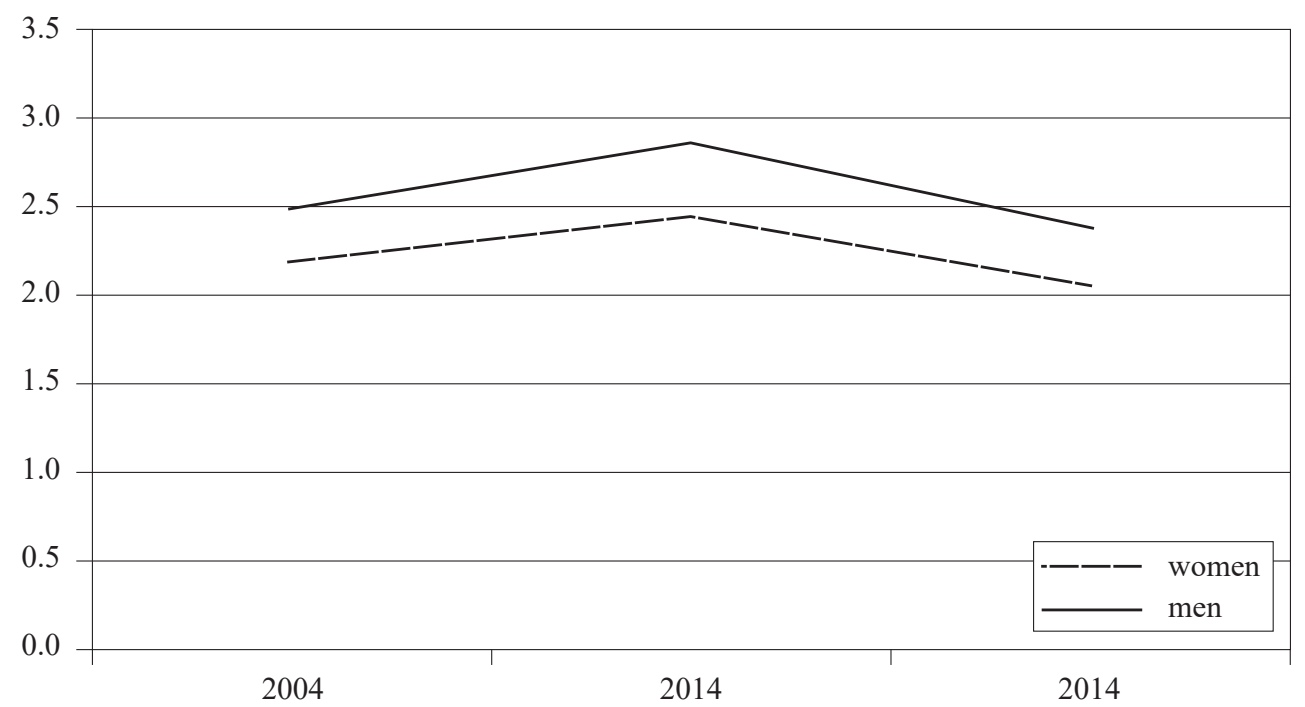

Source: Own elaboration. 
among women and men were respectively $\mathrm{M}=2.45 ; \mathrm{SD}=0.9$ and $\mathrm{M}=2.86, \mathrm{SD}=0.91$ $\left(\mathrm{F}=17.16 ; \mathrm{p}=0.000 ; \eta^{2}=0.04\right)$, while in $2014: \mathrm{M}=2.05, \mathrm{SD}=0.99$ and $\mathrm{M}=2.38$, $\mathrm{SD}=1.17\left(\mathrm{~F}=6.12 ; \mathrm{p}=0.013 ; \eta^{2}=0.02\right)$. This result proves the previous one: not only are men, to a greater degree than women, actually involved in conventional political activity, but it is also more important for them in a potential sense.

\section{The acknowledged values}

Analysis of the hierarchy of values in the following years indicates that the highest attractiveness, both for women and men, can be attributed to personal freedom, while the lowest assessments concern income equality.

The data indicates a statistical significance for differences in the assessment of “equality of remuneration,” „equality of opportunity,” „personal freedom” and „distribution of goods according to the needs of citizens" (women's advantage) and ,political freedom," „economic freedom" and ,equality before the law" (advantage of men). The result obtained in the group of women is a collection of values indicating the need for a safe standing in the social structure and, at the same time, free choice and action, which may be violated by the sense of security. Men appreciate freedom in given spheres of activities (politics and economy) and they hold equality before the law in a higher esteem.

In 2004, women valued equality of remuneration and equality of opportunity visibly more than men, while men outweigh women in terms of appreciation towards equality before the law and political freedom. In 2010, men more often than women preferred economic freedom, while women - equality of opportunity and division of wealth according to citizens' contribution. In 2014, women particularly appreciated the equality of opportunity, division of wealth according to citizens' needs and personal freedom, while men preferred economic freedom.

\section{Confidence about importance of political activity}

If the result „,0" denotes conviction that the activity is invalid, and the result „4" denotes the strongest conviction about the importance of activity, the average $\mathrm{M}=3.49, \mathrm{SD}$ $=0.92$ means that all of them highly value this form of involvement. At the same time, women reached the average of $\mathrm{M}=3.52 ; \mathrm{SD}=0.81$ and men $\mathrm{M}=3.31 ; \mathrm{SD}=1.11$, which is a statistically significant difference that indicates greater acceptance for this political activity in the women's group $\left(\mathrm{F}=8.80 ; \mathrm{p}=0.003 ; \eta^{2}=0.01\right)$.

In 2004, women achieved an average value of acceptance within values of political activity of $\mathrm{M}=3.70 ; \mathrm{SD}=0.59$ and men $\mathrm{M}=3.67 ; \mathrm{SD}=0.88(\mathrm{~F}=0.19 ; \mathrm{p}=0.660)$, which indicates lack of differences between the groups in the concerned scope. The situation is different in 2010: the average for women is $\mathrm{M}=3.70 ; \mathrm{SD}=0.64$ and men $\mathrm{M}=3.46 ; \mathrm{SD}=1.01\left(\mathrm{~F}=7.52 ; \mathrm{p}=0.006 ; \eta^{2}=0.02\right)$ and in $2014: \mathrm{M}=3.18 ; \mathrm{SD}=1.07$ vs $\mathrm{M}=2.80 ; \mathrm{SD}=1.32\left(\mathrm{~F}=6.50 ; \mathrm{p}=0.011 ; \eta^{2}=0.02\right)$ proving a greater acceptance for this value among women. 


\section{Satisfaction with democracy}

The scale of results assumes the minimum as „0" (no satisfaction) and the maximum as ,4" (the highest satisfaction). The surveyed group achieved an average result of $\mathrm{M}=1.34$; $\mathrm{SD}=1.05$, which indicates a rather unfavourable assessment of its state in Poland. At the same time, women have appraised it averagely reaching the result of $\mathrm{M}=1.37 ; \mathrm{SD}=1$, and men $\mathrm{M}=1.26 ; \mathrm{SD}=1.16(\mathrm{~F}=1.03 ; \mathrm{p}=0.310)$; the difference is not statistically significant.

In 2004, women reached the satisfaction level of $\mathrm{M}=1.09$; $\mathrm{SD}=0.96$ and men $\mathrm{M}=1.12 ; \mathrm{SD}=1.1(\mathrm{~F}=0.06, \mathrm{p}=0.798)$, and in $2010 \mathrm{M}=1.72$ respectively; $\mathrm{SD}=1.1$ and $\mathrm{M}=1.62 ; \mathrm{SD}=1.1(\mathrm{~F}=0.63, \mathrm{p}=0.426)$. In 2014 it was $\mathrm{M}=1.30 ; \mathrm{SD}=0,08$ and $\mathrm{M}=1.02 ; \mathrm{SD}=1.06\left(\mathrm{~F}=5.84 ; \mathrm{p}=0.016 ; \eta^{2}=0.02\right)$. Only the last result indicates greater satisfaction with democracy in the women's group. In this regard, men seem to be clearly frustrated.

\section{Individualism and collectivism}

On the scale of individualism with a minimum at 1 and maximum of 7 , the sourveyed group achieved an average of $\mathrm{M}=4.01 ; \mathrm{SD}=0.87$, which gives an indication of aboveaverage intensity of this orientation. Difference between women $(\mathrm{M}=3.89 ; \mathrm{SD}=0.83)$ and men $(M=4.25 ; S D=0.91)$ is statistically significant $\left(F=25.65 ; p=0.000 ; \eta^{2}=0.04\right)$ and indicates greater level of individualism in the men's group.

In 2010, the average value in the women's group was $\mathrm{M}=3.92 ; \mathrm{SD}=0.81$, and in the men's group $\mathrm{M}=4.29$; $\mathrm{SD}=0.95$, which indicates the significant advantage of men in terms of intensity at being individualistic $\left(F=15.20 ; p=0.000 ; \eta^{2}=0.04\right)$. Similar interdependencies manifest themselves in 2014: differences between averages $\mathrm{M}=3.86$; $\mathrm{SD}=0.86$ vs $\mathrm{M}=4.20 ; \mathrm{SD}=0.87$ are statistically significant $(\mathrm{F}=9.63 ; \mathrm{p}=0.002$; $\left.\eta^{2}=0,03\right)$.

On the scale for collectivism with a range of results from 1 to 7 , the researchers obtained an average result of $\mathrm{M}=4.56$; $\mathrm{SD}=0.82$, which proves a relatively high level of collectivism. The average value in the women's group is $\mathrm{M}=4.54 ; \mathrm{SD}=0.81$, and among men $\mathrm{M}=4.61 ; \mathrm{SD}=0.86$ : the difference is not statistically significant $(\mathrm{F}=0.85$; $\mathrm{p}=0.356)$.

In 2010, the average level of collectivism within the women's group was $M=4.54$; $\mathrm{SD}=0.82$ and in the men's group $\mathrm{M}=4.57 ; \mathrm{SD}=0.85(\mathrm{~F}=0.13 ; \mathrm{p}=0.722)$. In 2014 it was $\mathrm{M}=4.55 ; \mathrm{SD}=0.80$ vs $\mathrm{M}=4.66 ; \mathrm{SD}=0.89(\mathrm{~F}=1.12 ; \mathrm{p}=0.291)$. There are no significant differences between the surveyed genders within this scope.

Determinants of political activity: multiple regression analysis

The estimation has been conducted with a progressive step method, which allowed for avoiding problems with collinearity of descriptive variables. Factors which significantly affected levels of political activity have been determined based on the level of 
importance of the model parameter valuation. In turn, due to the differences in scales of explanatory variables, the hierarchy of significance related to factors taking part in the study was built on the basis of probability values (p-values). The following potential predictors were adopted in the analysis: the aforementioned eight values, conviction about the importance of political activity, satisfaction with democracy in Poland, individualism, and collectivism.

For the whole sample in all the years covered by the research, the model for conventional actual political activity has not achieved the required adjustment. All regression coefficients turned out to be insignificant.

Results of the regression analysis $\left(\mathrm{R}=0.45 ; \mathrm{R}^{2}=0.20\right.$; Adjusted $\mathrm{R}^{2}=0.19$; $\mathrm{F}(9,654)=18.32 ; \mathrm{p}<0.01)$ indicate that important factors influencing the conventional potential activity were arranged in the following order: belief in importance of activity (beta $=0.37, \mathrm{p}<0.000$ ), collectivism ( beta $=0.11, \mathrm{p}=0.002$ ), individualism ( beta $=0.10$, $\mathrm{p}=0.004$ ), equality before the law (beta $=0.10, \mathrm{p}=0.005$ ), and economic freedom (beta $=0.09, \mathrm{p}=0.011$ ).

Results for the both gender groups are as follows: for women the predictor of conventional actual activity (adjustment of the model: $\mathrm{R}=0.20 ; \mathrm{R}^{2}=0.04$; Adjusted $\left.\mathrm{R}^{2}=0.03 ; \mathrm{F}(4.366)=3.91 ; \mathrm{p}<0.01\right)$ is the "equality before the law" value (beta 0.114 ; $\mathrm{p}=0.030$ ) and conviction of the activity importance (beta $=0.11 ; \mathrm{p}=0.041)$. The level of conventional potential activity (adjustment of model: $\mathrm{R}=0.48 ; \mathrm{R}^{2}=0.23$; Adjusted $\left.\mathrm{R}^{2}=0.22 ; \mathrm{F}(7,440)=19.15 ; \mathrm{p}<0.01\right)$ depends on belief in importance of the activity (beta $=0.41, \mathrm{p}<0.000$ ), collectivism (beta $=0.14, \mathrm{p}=0.000$ ) and the value of ,personal freedom" (negative dependence; beta $=-0,09 ; \mathrm{p}=0.044$ ). In the group of men, the conventional actual activity (adjustment of model: $\mathrm{R}=0.24 ; \mathrm{R}^{2}=0.06$; Adjusted $\left.\mathrm{R}^{2}=0.04 ; \mathrm{F}(3,197)=3.86 ; \mathrm{p}<0.05\right)$ at the highest degree depends on the belief in importance of the activity (beta $=0.18, \mathrm{p}=0.011$ ) and acceptance of remuneration equality (beta $=0.15, p=0.038$ ), value of ,personal freedom" (negative dependence; beta $=-0$, $09 ; \mathrm{p}=0.044)$. The factor that determines the level of conventional potential activity (adjustment of model: $\mathrm{R}=0.44 ; \mathrm{R}^{2}=0.19$; Adjusted $\mathrm{R}^{2}=0.17 ; \mathrm{F}(5,210)=9.94 ; \mathrm{p}<0.01$ ) is conviction of the activity importance (beta $=0.37 ; \mathrm{p}=0.000$ ).

\section{Discussion}

The hypothesis that gender differentiates level of political activity has been positively verified in most of the conducted analyses. Conventional actual political activity turned out to be considerably closer for men than women. This difference was confirmed by the research conducted in each year except 2014. On the other hand, men turned out to be more interested in conventional potential political activities. As far as this scope is concerned, the results obtained for all the years as a whole as well as the results for respective research stages were higher. Importantly, other results from research conducted in a different age group (11-17 years of age) were obtained by Anna M. Zalewska and Beata Krzywosz-Rynkiewicz (2011), who analysed the relationship between developmental and subjective factors with civic activity of the young, including political activity. These studies have shown that level of political activity (declared conventional activity) does 
not depend on gender. The only factor out of variables that include gender, age and the place of residence which turned out to have significance for this form of civic activity was the third one. Young people from smaller cities displayed greater readiness to be politically active in the future. Differences in the level of civic behaviour between girls and boys were revealed only in the field of passive citizenship (sense of national identity and patriotism) and social activity (e.g. fundraising, volunteering, participation in local actions). Thus, it is possible to formulate a hypothesis that potential conventional activity becomes more important in the period of early adulthood.

In both groups of women and men, the most preferred value is personal freedom, while equality before the law or equality of opportunity takes the second place. Similarly, the most rarely selected values in both groups referred to equality of remuneration and division of wealth according to citizens' needs. Some of the analyses indicate significant differences in preference for a given value among representatives of one of the genders, but this does not significantly change their hierarchy. Out of all values included in the analyses, only some of them turned out to be significant predictors of political activity. Equality before the law affects the level of conventional actual activity in the group of surveyed women, while in the same group the equality of remuneration affects the level of unconventional legal potential activity. On the other hand, acknowledgement for equality of remuneration has an importance for conventional actual activity among men, a lack of appreciation for personal freedom is related with a tendency to conventional potential activity. A value which has not been included in the analyses yet presents significance to political participation, is an experience of being secure. In the women's group it acts as a predictor of individual and collective political activities (Klamut, 2014).

The second detailed hypothesis regarding expected higher support for importance of political activity in the group of men was not confirmed in the obtained results because it turned out that women are more convinced of its importance. Such a conclusion is the result of analysing data from all the years together and separately the years 2010 and 2014. No difference has been observed only with regard to the data from 2004. Conviction about importance of political activity seems to be the most stable predictor of women's involvement and it is important for each type of activity. This interdependency proves itself for men only in the case of the conventional activity.

The hypothesis about a greater level of satisfaction with democracy in the group of surveyed men has also been verified negatively. Most of the conducted research does not allow for drawing such a conclusion. Only the 2014 data prove the differences. In this example, however, higher satisfaction with democracy was observed among women.

Results of analyses concerning differences in the level of collectivism between women and men suggest to disregarding he hypothesis about its higher level in the women's group. On the other hand, significant differences were noted in the level of individualism. Its level turned out to be much higher in the group of surveyed men. Along with its increase the tendency to undertake political activity of unconventional, illegal and potential nature also increases. Collectivism has a varying impact on political activities in women, as opposed to men. In relation to women, it affects tendencies for starting conventional potential activities, while in relation to men it affects unconventional legal potential activities. 
As shown by the above results, women and men differ not only at the levels of political activity, but also differ when it comes to its conditions. Analysis of dynamics of those changes as well as determinants of political activities among women and men allows for drawing the following conclusions.

The level of conventional actual activity was diagnosed to be the highest in 2004 both among women and men, although it was significantly higher among men than women. In 2010 it has considerably decreased in both groups, yet still men were found to be more active to a greater degree. On the other hand, data from 2014 indicate a significant increase in this type of activity among women and a slight increase among men, so that no significant differences were observed between representatives of both genders in its level. Taking into account the data collected at all stages of the study, the variables determining the level of conventional actual activity include primarily the conviction about importance of the activity and recognition for equality before the law in a group of women and recognition of equality of remuneration in the group of men.

In all stages of the research, differences in the level of conventional potential activity between representatives of both genders have been maintained. What is more, its average level was relatively stable (with a slight increase in 2010). The predictors for this type of activity included primarily the conviction about importance of activity, and for women: collectivism as well as the lack of recognition of values of personal freedom.

The research context seems to have no importance for the level of conventional political activity among the surveyed. This may be a result of the fact that the research was carried out in years accompanied by events that lower confidence in politics and politicians and discourage involvement. In addition, in each case the research covered young people, usually less interested in this area of activity, as indicated in the introduction when characterizing the studied group (see also: Liberska, 2004; Szafraniec, 2012; Turska-Kawa, 2012; Marzęcki, 2013).

To a significant degree, the trends of changes in political activities revealed by researches comply with the changes being observed in this scope. A lot of research on political participation (European Values Study, World Values Study) registers a decrease in citizens' interest in activity, especially those of conventional nature. Discouragement and lack of trust in the political elite and political parties results in a decrease in the voter turnout in most countries - both in mature democracies as well as the new ones. What is more, membership in political parties, which is a basic, conventional activity, is also decreasing (Rucht, 2010).

In turn, slow blurring of previously observed differences in political activity between women and men is also observed in other studies, especially those conducted in countries being more advanced in the modernization process (e.g. Coffe, Bolzendahl, 2010; Norris, 2002). As R. Inglehart and P. Norris point out, the shift towards post-materialist values that accompany these processes favours equalization of the position of women and men in the political area as well (Inglehart, Norris, 2009). The fact that in the concerned studies gender ceased to be a factor differentiating level of both conventional and unconventional legal political activity only in 2014 allows the suspicion that this change has only just begun (see results of research on values, e.g. Bartkowski, 2009; Jasińska-Kania, 2011).

The most doubtful and questionable are the results that refer to conditions of political activities taken up by women and men. It is difficult to identify the factor which is con- 
ducive to undertaking political activity in both surveyed groups to the same extent. An important predictor of any type of activity among women was the belief in importance of being active in democracy, which for men was only important in the case of conventional activities. Obviously, it is not strange that undertaking political activity is related to conviction that the said activity is important (more about relationship between political participation and attitudes and beliefs see: Quintelier, van Deth, 2014). It is worth noting, however, that women's conviction about the importance of activity in democracy is growing, which may be the result of intensified actions carried out by feminist organizations stressing the importance of mobilising women in the political sphere. The fact that it is accompanied by an increase in political activity among the surveyed women may be an indication of interdependency between those factors.

On the other hand, interdependencies between individualistic or collective orientation and political activity of women and men were more complex. According to the assumption, men had stronger individualistic orientations than women. Support for unconventional illegal activity has been increasing together with the increase in individualism, which cannot be regarded as a surprise. Activities of this type undermine the existing rules and they are often a manifestation of a rebellion against the rules imposed by a dominant group. However, the picture of interdependencies was more complicated in the case of collectivism. In case of women, it caused greater support for potential conventional activity (which is in line with expectations - participation in elections can be treated as an expression of support for group norms and attention to social order). In the case of men, however, it translates into higher support for unconventional legal activity.

Furthermore, the noticed interdependencies between importance of given political values and political activity create a complex and vague image. While the dependencies between political activity and the choice of equality before the law or political freedom that have been found in the group of women can be explained, a link between equality of remuneration and political activity (found in the group of men) is more difficult to explain. It seems that it would be worth carrying out more in-depth research focused only on relationship between political values and political activity of women and men.

Conducting this type of research on the relationship between gender and political activity is important in the context of controversies related to quotas introduced in the Polish political system as well. According to opponents of this type of solution, such artificial activation of women may cause them to enter politics by accident, because the number of females who are really interested in this sphere is smaller than the number of men. Detection of factors determining the level of political activity among women and men brings us closer to answering the question of where the possible differences in this activity come from.

Although the research was conducted on a relatively small group (young people, who were still students ${ }^{1}$ ), and as such does not give grounds to generalize the results, it does not mean they are not very important. Research conducted among students helps to identify certain trends in changes within the sphere of activities among men and women.

${ }^{1}$ Among students there were students of political science, which could suggest their greater interest in political activity, but analyses carried out for the purposes of another article indicated that differences related to the field of study in the subsequent years of research tend to fade away (see also: Miluska, Pająk-Patkowska, 2014). 
Young people, especially well-educated, are the first carriers of specific attitudes that will probably appear in future society (Koseła, 1999; Rogowska, 2000; Szafraniec, 2011; Szafraniec, 2012). Krystyna Szafraniec emphasizes that „young people are a very good point of reference for observing what is happening to the whole society. [...] It is a barometer of changes and social moods" (Szafraniec, 2011, p. 11). By examining it, one can try to answer the question: ,what will be the shape of Polish social life in the future and what role will young people play in it" (Zalewska, Krzywosz-Rynkiewicz, 2011, p. 238).

It is worth emphasizing that keeping track of conventional political activities and their evolution is also vital from the perspective of democratic system stability and legitimacy. Researchers working on this subject cannot agree which degree of political activity (whether low or high and respectively how low or how high) poses a threat to stability of democracy. However, citizens' participation in elections is identified as a crucial factor allowing to consider political elites and the democratic system itself legitimate (Mider, 2013; Dzwończyk, 2011; Pająk-Patkowska, 2015). Joanna Dzwończyk points to an important issues connected with political activities. According to her opinion, besides obvious relation between participation in elections and legitimacy of the political system, it is also vital to note that a high turnout constitutes ,a some kind of a mechanism which safeguards against such detrimental factors as over-participation and over-parliamentarisation. The first one refers to appropriation of public space by political parties, while the latter makes parliament the only place of political debate, which can be negatively perceived by the society if it becomes unrepresentative due to low turnout" (Dzwończyk, 2011). This may be particularly dangerous for young democracies, among which the Polish democracy should still be counted, because it undermines trust in democracy and the solutions which it advocates.

\section{Bibliography}

Adman P. (2009), The Puzzle of Gender-equal Political Participation in Sweden: The Importance of Norms and Mobilization, "Scandinavian Political Studies," 32, 3, pp. 315-336.

Ashmore R. D., Del Boca F. K. (1981), Conceptual Approaches to Stereotype and Stereotyping, in: Cognitive Process in Stereotyping and Intergroup Behaviour, ed. D. L. Hamilton, Erlbaum, NJ, pp. 1-36.

Barner-Barry C., Rosenwein R. (1991), Psychological perspectives on politics, Waveland Press, Long Grove.

Barnes S. H., Kaase M. (1979), Political Action: Mass Participation in Five Western Democracies, Sage Publications, Beverly Hills.

Bartkowski J. (2009), Wartości materialistyczne i postmaterialistyczne w Polsce w ujęciu porównawczym, in: Wartości - polityka - społeczeństwo, eds. M. Zahorska, E. Nasalska, Wydawnictwo Naukowe Scholar, Warszawa, pp. 33-47.

Bolzendahl C., Coffe H. (2013), Are 'Good' Citizens 'Good' Participants? Testing Citizenship Norms and Political Participation across 25 Nations, "Political Studies," 61, S1, pp. 45-65, doi: 10.1111/1467-9248.12010.

Bolzendahl C., Coffe H. (2009), Citizenship beyond politics: the importance of political, civil and social rights and responsibilities among women and men, "The British Journal of Sociology," 60, 4, pp. 763-791, doi: 10.1111/j.1468-4446.2009.01274.x. 
Cassese E. C., Holman M. R. (2016), Religious Beliefs, Gender Consciousness, and Women's Political Participation, "Sex Roles," 75, 9, pp. 514-527.

Chhibber P. (2002), Why are Some Women Politically Active? The Household, Public Space, and Political Participation in India, "International Journal of Comparative Sociology," 43, 3-5, pp. 409-429.

Coffe H., Bolzendahl C. (2010), Same Game, Different Rules? Gender Differences in Political Participation, "Sex Roles," 62(5-6), pp. 318-333.

Cześnik M. (2009), Partycypacja wyborcza w Polsce, Instytut Spraw Publicznych, Warszawa.

Dalton R. J. (2008), Citizenship Norms and the Expansion of Political Participation, "Political Studies," 56, pp. 76-98.

Deaux K., Kite M. (2002), Stereotypy ptci, in: Kobiety i mężczyźni: odmienne spojrzenie na różnice, ed. B. Wojciszke, GWP, Gdańsk, pp. 354-379.

Dzwończyk J. (2011), Poziom frekwencji wyborczej jako czynnik legitymizacji władzy, „Horyzonty polityki," nr 2.

Eagly A. H. (1987), Sex differences in social behaviour: A social - role interpretation. Hillsdale, Erlbaum, New York.

Gelb J., Palley M. L. (eds.) (2009), Women and Politics Around the World: A Comparative History and Survey, ABC Clio, Santa Barbara.

Graziano P. R., Forno F. (2012), Political Consumerism and New Forms of Political Participation: The „, Gruppi di Acquisto Solidale” in Italy, "The Annals of the American Academy of Political and Social Science," vol. 644, Communication, Consumers, and Citizens: Revisiting the Politics of Consumption, pp. 121-133.

Halman L., Voicu M. (2010), Mapping Value Orientations in Central and Eastern Europe, Brill, Leiden.

Harwas-Napierała B., Trempała J. (2000), Psychologia rozwoju człowieka, t. 2, PWN, Warszawa.

Hofstede G. (2007), Kultury i organizacje, PWE, Warszawa.

House J. (1981), Social structure and personality, in: Social psychology: Sociological perspectives, eds. M. Rosenberg, R. Turner, Basic Books, New York, pp. 525-561.

Inglehart R., Norris P. (2009), Wzbierająca fala, PIW, Warszawa.

International IDEA (2015), http://www.idea.int/.

Jasińska-Kania A. (2011), Dynamika zmian wartości Polaków na tle europejskim: EVS 1990-19992008, in: Polska po 20 latach wolności, eds. M. Bucholc, S. Mandes, T. Szawiel, J. Wawrzyniak, Wydawnictwo Uniwersytetu Warszawskiego, Warszawa, pp. 225-239.

Kaase M. (2000), Politische Beteiligung/Politische Partizipation, in: Handwörterbuch des politischen System der Bundesrepublik Deutschland, eds. U. Andersen, W. Woyke, Bundeszentrale f. Politische Bildung, Bonn.

Klamut R. (2014), Zależność pomiędzy doświadczanym poziomem bezpieczeństwa a aktywnościa obywatelska z uwzględnieniem modyfikującej roli płci, „Humanitesand Social Science,” XIX, 21, pp. 67-81.

Koseła K. (1999), Młodzież szkolna o rynku i demokracji, Oficyna Naukowa, Warszawa.

Kwiatkowska A. (2010), Koncepcja obywatelstwa w teorii feministycznej, in: Praktyki obywatelskie Polaków, ed. J. Raciborski, Wydawnictwo IFiS PAN, Warszawa.

Li Y., Marsh D. (2008), New Forms of Political Participation: Searching for Expert Citizens and Everyday Makers, "British Journal of Political Science," 38,2, pp. 247-272.

Liberska H. (2004), Perspektywy temporalne młodzieży. Wybrane uwarunkowania, Wydawnictwo Naukowe UAM, Poznań.

Marsh D., Akram S. (2015), Political participation and citizen engagement: beyond the mainstream, "Policy Studies," 36, 6, pp. 523-531. 
Marzęcki R. (2013), Młody obywatel we wspótczesnej demokracji europejskiej, Dom Wydawniczy Elipsa, Warszawa.

Mider D. (2013), Partycypacja polityczna a legitymizacja systemu politycznego, „Studia Politologiczne," vol. 18.

Miluska J. (1996), Tożsamość kobiet i mężczyzn w cyklu życia, Wydawnictwo Naukowe UAM, Poznań.

Miluska J., Pająk-Patkowska B. (2014), Społeczno-demograficzne uwarunkowania aktywności politycznej w procesie transformacji systemowej, „Przegląd Psychologiczny,” 57, 1, pp. 107-121.

Norris P., Walgrave S., van Aelst P. (2002), Who demonstrates? Anti-state Rebels, Conventional Participants or Everyone, http://www.hks.harvard.edu/fs/pnorris/Acrobat/Who\%20demonstrates. pdf.

Norris P. (2007), New feminist challenges to the Study of Political Engagement, in: The Oxford Handbook of Political Behavior, eds. R. J. Dalton, H.-D. Klingemann, Oxford University Press, New York.

Quintelier E., van Deth J. W. (2014), Supporting Democracy: Political Participation and Political Attitudes. Exploring Causality Using Panel Data, "Political Studies," 62, pp. 153-171, doi: 10.1111/1467-9248.12097.

Pająk-Patkowska B. (2011), Przesłanki stabilności demokracji - legitymizacja systemu na poziomie indywidualnym, „Środkowoeuropejskie Studia Polityczne,” nr 1.

Pankowska D. (2005), Wychowanie a role społeczne, GWP, Gdańsk.

Pratto F. (2002), Polityka ptci: różnice pomiędzy kobieta a mężczyzną w sypialni, kuchni i gabinecie, in: Kobiety i mężczyźni: odmienne spojrzenie na różnice, ed. B. Wojciszke, GWP, Gdańsk.

Reykowski J. (1990), Ukryte założenia normatywne jako osiowy sktadnik mentalności, in: Orientacje społeczne jako element mentalności, eds. J. Reykowski, K. Skarżyńska, M. Ziółkowski, Wydawnictwo Nakom, Poznań.

Roewe P. (2015), Mama Bakers as Everyday Makers: the political is personal, "Policy Studies," 36, 6, pp. 623-639.

Rogowska B. (ed.), (2000), Młode pokolenie Polski, Wydawnictwo Uniwersytetu Wrocławskiego, Wrocław.

Rosenstone S. J., Hansen J. M. (2003), Mobilization, Participation, and Democracy in America, Longman, New York.

Ross A., Dooly M. (2010), Political understanding, participation and action, in: Future Citizens. $21^{\text {st- }}$ centurychallenges for young people, eds. B. Krzywosz-Rynkiewicz, A. Zalewska, A. Ross, Impuls, Kraków, pp. 283-312.

Rucht D. (2010), Rosnace znaczenie polityki protestu, in: R. J. Dalton, H.-D. Klingemann, Zachowania polityczne 2, PWN, Warszawa, pp. 349-369.

Skarżyńska K. (1997), Sprzeciw, poparcie, czy “dawanie świadectwa wartościom” - co motywuje Polaków do aktywności politycznej, in: Psychologia rozumienia zjawisk społecznych, eds. B. Wojciszke, M. Jarymowicz, PWN, Warszawa, pp. 39-60.

Skarżyńska K. (2002), Aktywność i bierność polityczna, in: Podstawy psychologii politycznej, ed. K. Skarżyńska, Zysk i S-ka, Poznań, pp. 26-58.

Skarżyńska K. (2005), Człowiek a polityka. Zarys psychologii politycznej, Wydawnictwo Naukowe Scholar, Warszawa.

Sotwin W. (2003), Podmiotowość w sferze politycznej, czyli pragmatyzm-pryncypializm, Wydaw. Naukowe Scholar, Warszawa.

Szafraniec K. (2011), Wprowadzenie, in: Młodzież 2011, ed. M. Boni, Kancelaria Prezesa RM, Warszawa.

Szafraniec K. (2012), Dojrzewający obywatele dojrzewającej demokracji. O stylu politycznej obecności młodych, Instytut Obywatelski, Warszawa. 
Theocharis Y., van Deth J. W. (2016), The Continuous Expansion of Citizen Participation: A New Taxonomy, "European Political Science Review," s. 1-24, https://doi.org/10.1017/S175577391600023.

Turska-Kawa A. (ed.), (2012), Polityka w opinii młodych, Wydawnictwo US, Katowice.

van Aelst P., Walgrave S. (2001), Who is that (wo)man in the street? From the normalization of protest to the normalization of the protesters, "European Journal of Political Research," 39 (4), pp. 461-486.

van Deth J. (1986), A note on measuring political participation in comparative research, "Quality and quantity," 20, 2, pp. 261-272.

van Deth J. (2012), New Modes of Participation and Norms of Citizenship, in: New participatory dimensions in civil society, eds. J. W. van Deth, W. A. Maloney, Routledge, London.

van Deth J. (2016), What is political participation, in: Politics. Oxford Research Encyclopedias, doi: 10.1093/acrefore/9780190228637.013.6.

Verba S., Schlozman K. L., Brady H. (1995), Voice and Equality. Civic voluntarism in American Politics, Harvard University Press, Cambridge.

Welch S. (1977), Women as political Animals? A test of some Explanation for Male-Female Political Participation Differences, “American Journal of Political Science," vol. 21, no. 4, pp. 711-730.

Zalewska A. M., Krzywosz-Rynkiewicz B. (2011), Psychologiczne portrety młodych. Rozwojowe i podmiotowe uwarunkowania aktywności obywatelskiej młodzieży, Wydawnictwo SWPS Academica, Warszawa.

Żukowski A. (2011), Partycypacja wyborcza kobiet - wyzwania i dylematy, Towarzystwo Naukowe Organizacji i Kierownictwa Dom Organizatora w Toruniu, Torun.

\title{
Aktywność polityczna kobiet i mężczyzn - psychospołeczne uwarunkowania konwencjonalnej działalności politycznej
}

\begin{abstract}
Summary
Aktywność polityczna jest jednym z rodzajów aktywności społecznej człowieka. Obserwacje i badania wskazują na znaczenie płci jako czynnika decydującego o jej poziomie i formach. Poza płcią biologiczną kształtującą role społeczne kobiet i mężczyzn, dodatkowymi czynnikami potencjalnie odpowiedzialnymi za ich aktywność, są elementy systemu przekonań, czyli uznawane wartości polityczne, przekonanie o wartości aktywności politycznej, poziom zadowolenia z demokracji oraz indywidualizm i kolektywizm traktowany jako element mentalności jednostki. Wpływ tych czynników na poziom konwencjonalnej aktywności politycznej kobiet i mężczyzn jest przedmiotem badań kwestionariuszowych przeprowadzonych w roku 2004, 2010 i 2014 na grupie 1048 studentów polskich uczelni. Uzyskane wyniki wskazują na powolne zanikanie różnic w poziomie aktywności politycznej badanych kobiet i mężczyzn oraz zróżnicowane jej uwarunkowania w obu grupach i w zależności od formy aktywności. Najważniejszymi predyktorami aktywności politycznej kobiet są: przekonanie o wadze aktywności w demokracji oraz (nie)zadowolenie z jej funkcjonowania.
\end{abstract}

Słowa kluczowe: Słowa kluczowe: aktywność polityczna, płeć, działalność polityczna kobiet, młodzież, teoria roli społecznej 
